\title{
Chinese officers in Cirebon
}

\author{
SteVe Haryono
}

\begin{abstract}
The city of Cirebon was not as large as Batavia (Jakarta) or Semarang, but its location on the northern shore of Java made it an important harbour city from which the inland regions of the southern part of West Java could be serviced. As a harbour town, Cirebon became the regional centre of trade and commerce, and many Chinese immigrants settled there. As were other cities, Cirebon fell under the governance of the VOC and later of the Netherlands Indies administration A Chinese officer was appointed to deal with Chinese community issues in the region. With the exception of the well-known Major (Majoor der Chinezen) Tan Tjin Kie, whose funeral is described in his son's book, little is known about the other Chinese officers in Cirebon. Most publications concentrate on the Chinese officers in Batavia or Semarang or in other large cities. Numerous Chinese officers were appointed in Cirebon and in the surrounding regions. Many of them were members of four or five big families. This article describes their lives, families, and descendants, their businesses, and their whereabouts.
\end{abstract}

KEYWORDS

Chinese officers in Cirebon; Netherlands Indies.

\section{Prologue}

When they held sway over the Indonesian Archipelago both the VOC (Verenigde Oostindische Compagnie) and later the Netherlands Indies government imposed a division on the inhabitants, segregating them into three population groups. The first and the highest in rank were Europeans, the lowest were the natives or the local indigenous inhabitants and in between were the immigrants from foreign Asian countries (Vreemde Oosterlingen). These could be of Chinese, Arab or Indian descent.

As the primary reason the Dutch came to Indonesia was for trade and commerce, they did not have the manpower to run many aspects of the administration of the subjected regions. They left the Bupati (regional head of

STEVE HARYONO, born in Cirebon and raised in Jakarta until finishing highschool at Canisius College. Moved in 1975 to the Netherlands to pursue further study in Technische Hogeschool Delft. Started to collect family trees especially for Chinese Indonesian Peranakan families in 2003. Collections now consist about 150 family trees; some of them a complete book and others just a diagram on a piece of paper. Steve Haryono can be contacted at: steve.haryono@gmail.com. 
the regency) to administer the local indigenous inhabitants, installed a Chinese Captain to take care of the Chinese community's affairs and appointed an Arab Captain to run the organization of the Arab community. In a nutshell, by and large the Dutch preferred to communicate with "leaders" of the ethnic communities and to leave these "leaders" to be responsible for maintaining law and order, for instance, preventing riots.

The Chinese officers were not paid a salary by the Dutch colonial government; therefore, it obviously only a rich Chinese would qualify to become an officer who would be highly regarded as a respected officer in the Chinese community. This officer had the duty to ensure that no community problems arose among the Chinese themselves. A Chinese officer also needed to be able to act as a mediator if two Chinese came to him with their dispute. Unless an officer was highly regarded among his own people, how could his decisions be respected or accepted by his people? Sadly enough, in the eighteenth and the nineteenth century, the only yardstick by which to win community respect was wealth. Only at the beginning of the twentieth century could that respect be earned by a profession and higher education. Paradoxically, this time was also the beginning of the decline of Chinese officer-ship in the Netherlands Indies.

By becoming an officer, a Chinese could acquire some privileges that would help him win concessions in various areas of business. A concession can be compared to a monopoly in trading in some items in a particular region, for example: tax collection, pawnshops, organizing public markets, transportation, construction, supplying/logistics and many other economic pursuits. Although the concession (pacht) was theoretically open to any male member of the public, it was common knowledge that only a wealthy man would have any hope of acquiring one.

In the beginning, after the Dutch had acknowledged the need to appoint a Chinese officer, they would install the most prominent person in the Chinese community in the town as captain (Kapitein der Chinezen). ${ }^{1}$ As a city grew larger, the need arose to appoint a second officer and, to fulfill this duty, they would recruit a lieutenant (Luitenant der Chinezen) to assist the captain. In a big city like Batavia, Semarang, and Surabaya in Java, homes to many Chinese people, the higher-ranking title of major (Majoor der Chinezen) was accorded to their leader. He would be assisted by one or two captains and various (four to six) lieutenants. In Cirebon, a medium-large city, initially there was only one captain. It was in the year of 1842 that the first Lieutenant was installed. Hence, in Cirebon, the captain was the highest rank for all Chinese officers.

Alongside the common ranks of the Chinese officers, there were also honorary ranks such as Honorary Major, Honorary Captain, and Honorary Lieutenant. These ranks, as the word suggests, were awarded largely to enhance the esteem of those particular persons. Some of these titles were awarded by the Dutch and some were paid for by the persons themselves. In the first case, the rank was normally accorded either when an officer had 
performed his job well or after a long period of service. After he submitted a request for retirement, the Dutch would agree and grant him an honorary rank. Some of them would be elevated to a higher rank, but some were not. Sometimes the Dutch bestowed the honorary rank before retirement as a reward for good service. In the second case, as said some wealthy Chinese could also buy the honorary title to improve their esteem among their fellow Chinese.

The Chinese officer-ship was not inherited from father to son or between brothers. Nevertheless, an active officer did have a big say in the appointment of his successor. In a normal situation, the Dutch head of the region (de Resident) would ask the incumbent office-holders for advice about who the next candidate should be. The Dutch obviously preferred a candidate who could be trusted, and preferred not to appoint an unknown Chinese candidate whose loyalty might be dubious. As being an officer was a very important task, it was logical that the incumbent officer would give preference to a candidate from among his own family or clan members (namely: family and clan interdependency?).

\section{Cirebon REGENCY}

Before the creation of the province of West Java, the western part of Java was already divided in five areas: Batavia, Banten, Buitenzorg (Bogor), Preanger, and Cirebon. The Cirebon regency itself was subdivided into smaller regions on the prefectural level. These regions were Indramayu, Majalengka, Kuningan, and Galuh (Tasikmalaya had also been under Cirebon in the past), apart from the Cirebon prefecture itself. In the Cirebon prefecture, there was a division in the administrative regions of the Chinese officers. For instance, a lieutenant was appointed in the village of Jamblang, whose administrative regions were west and northwest of Cirebon city. The lieutenant in the village of Ciledug, was responsible for the eastern and southeastern regions of Cirebon. Cirebon itself had its own lieutenant, and the captain was obviously responsible for the entire region. This article discusses only the officers in the Cirebon prefecture.

Unlike the big cities in Java such as Batavia, Semarang, and Surabaya, in which official Chinese councils or Kong Koan (Chinese Raad) had been set up, there was no such body in Cirebon. However, because of the administrative structure which included more than one officer in the city, meetings were definitely between the officers. The whereabouts of the minutes of meetings of the officers are unknown, and no important documents actually written by the Chinese officers in Cirebon have been found. The situation after 1965 in the wake of the anti-China campaign of the Suharto regime has made it even more difficult to investigate the existence of such archival materials.

\section{VARIOUS SOURCES}

The principal information about the Chinese officers in Cirebon has been gathered from their family stories. The families Tan, The, Kwee, and Oey were 
important Cirebon families and their descendants can still be traced today. Each has their own family tree and family stories.

Chinese temples in which inscriptions on wooden plaques are preserved are another important source of information about Chinese community members in the cities. The temples are gathering place for members of the Chinese community, and renovations are frequently carried out for the repair and maintenance of the temples. In the past, it was usual at that time that, once a renovation had been planned, the administrator of the temple would request donations from the local Chinese community to cover the expenses. To express gratitude to the donors, a wooden plaque carved with a small introduction composed by the officer and the names of all the donors would usually be placed in a prominent position near the temple wall or at the entrance.

There are three Chinese temples in Cirebon, the "Tiao Kak Sie", the largest temple in Cirebon, the "kelenteng Talang", the oldest, formerly the ancestral hall of the Tan family, and the last is the "Boen San Tong". Another old Chinese temple that possesses historical information is situated in the village of Jamblang, just fifteen kilometers west of Cirebon. There is also Chinese temple in Ciledug but, compared to the other four, this temple is relatively new and does not preserve any old artefacts such as wooden plaques dating from the nineteenth century.

The Regerings-almanak der Nederlandsch Indië was issued every year, commencing in 1815 and every year thereafter until 1942. This publication contains the names of Chinese officers in every city in the Netherlands Indies, sometimes with the date of their installation. This is an enormous help as there have been some difficulties in deciphering the names on the wooden plaques from the Chinese temples, as most of the time the officers would give their "trade" names to be written on these wooden plaques. Therefore, these names can be different from the names of the persons known to the public in the Chinese community. For example, on a wooden plaque dated 1889 is a record that the renovation was initiated by Captain The Ek Goan in 1887 and completed by his successor, Captain Tan Bang Hoen. ${ }^{2}$ In the Regeringsalmanak we read that in 1887 the Captain's name was The Tjiauw Tjay, and his successor was Tan Tjin Kie.

The digitized colonial newspapers available in the Dutch Royal Library (Koninklijk Bibliotheek) ${ }^{3}$ also gives us more information about the installation

2 In the past, a wealthy Chinese had at least three names. In the case of Captain The Tjiauw Tjay, the name Tjiauw Tjay was his given name. After he became successful, he took the name Ek Goan as his trademark. On the wooden plaque, his name is not written as The Tjiauw Tjay, but as The Ek Goan. After he passed away, the name written on the gravestone was different again, The Tjoen Yan. This was his posthumous name. In the case of Major Tan Tjin Kie, in his son's book we read that he had a second name, which was Tan Keng Bie, and from the wooden plaque we learned that his name was Tan Bang Hoen. As we were unable to locate his gravestone, we do not know his posthumous name. So, it seems that Tan Tjin Kie might have had at least four different names.

3 See http://www.delpher.nl. 
of the officers and their businesses, including their bankruptcies and other important matters.

\section{The officers before Captain TAN PHAn Long}

The first Chinese officer registered in the Regerings-almanak is Captain Tan Phan Long in 1836, although, as said, information about earlier officers can be retrieved from the wooden plaques in the Chinese temples. Franke, Salmon, and $\mathrm{Hu}$ (1997) say that the Tiao Kak Sie Temple had already existed in the time of Captain Tan Siang Ko, in the period between 1705 and 1720. On the wooden plaque dated 1790, Captain Tan Oat Ing writes that this temple was a virtual ruin, and that he, with the financial support of donors from outside Cirebon, had repaired and enlarged it. ${ }^{4}$ The next renovation of the temple was in 1823, and it took until 1830 before this was finally completed. On the wooden plaque, dated 1830, ${ }^{5}$ Captain Tan Kong Djan explains that the renovation had been initiated by Captain Tan Soe Tje in 1823. So, we can assume that Captain Tan Soe Tje passed away between 1823 and 1830. A newspaper from $1837^{6}$ contains the announcement of the passing of the former Captain of Cirebon, Tan Jong Goan, placed by his executor Tan Nge Lam. The most plausible assumption is that Captain Tan Jong Goan succeeded Captain Tan Kong Djan but had died before 1836 and was succeeded in turn by Captain Tan Phan Long.

On the wooden plaque dated 1889 that commemorates the next renovation, the Captain at that time, Tan Tjin Kie, explains that the earlier renovation of 1823 had been completed by his great-grandfather, Captain Tan Kong Djan. In the family tree of Major Tan Tjin Kie, the name of his grandfather is written Tan Kim Lin, and he had also been installed as Captain. In her dissertation, Chen Menghong also writes that both Tan Kim Lin and his brother, Tan Phan Long, were captains (Chen Menghong 2011). Tan Kim Lin died in 1835. So, if he was indeed the Captain of Cirebon, he must have been in power before Tan Phan Long. Looking at the newspaper clippings from 1837, there is a possibility that Captain Tan Jong Goan and Captain Tan Kim Lin were one and the same person. Also, the eldest son of Captain Tan Kim Lin, who later became Captain Tan Tiang Keng, was nine years old when his father died. As his son was a minor, it is plausible that an adult would have had to assume the role of Tan Kim Lin's executor.

\section{OFFICERS BETWEEN 1836-1874}

Captain Tan Phan Long was first registered as a Chinese officer in Cirebon in the Regerings-almanak in 1836. It does not mention when he was officially appointed. So, it is possible that he was installed in 1835 when his brother, Captain Tan Kim Lin (Tan Jong Goan), passed away. From a newspaper article of $1834,{ }^{7}$ we learn that he was married to Ang Soen Nio and one of

\footnotetext{
Franke, Salmon, and Hu 1997 II/1: 195.

Franke, Salmon, and Hu 1997 II/1: 202.

Javasche Courant 9-9-1837: 6.

Javasche Courant 9-7-1934: 6.
} 
his daughters was Tan Boen Nio. The marriage register ${ }^{8}$ of the Batavia Kong Koan Archives records the fact that in 1822 this daughter, Tan Boen Nio, was married to Ong Peng Oen, and in 1827 Tan Tjoan Leng's son was married to Liem Hong Nio. On both occasions, Captain Tan Phan Long was the witness as father of the bride and groom respectively.

Both Tan Kim Lin and Tan Phan Long were brothers of Tan Pin Long, ${ }^{9}$ a lieutenant in Batavia between 1830 and 1837. Tan Pin Long's son, Tan Siauw Tjoe, was an honorary lieutenant and member of the Wees- en Boedelkamer. ${ }^{10}$ Lieutenant Tan Siauw Tjoe was one of the few Chinese officers who were sacked by the government. He was found guilty of smuggling opium in 1847 and dismissed from his membership of board of the Wees- en Boedelkamer. In 1849 , he was reinstated but sacked again in $1854^{11}$ as he had been found guilty of possessing opium.

Captain Tan Phan Long served until 1846, when he probably retired. In recognition of his service, Tan Phan Long was allowed to use the title Honorary Captain. He died in $1848^{12}$ and was buried in the Kali Tanjung Cemetery. His gravestone records that he had two wives, four sons, and four daughters. With the exception of Tan Tjoan Leng and Tan Boen Nio, who were married in Batavia, there were no traces of any other descendants of Captain Tan Phan Long.

It is known that Captain Tan Phan Long attended the wedding ceremonies of his nephew, Tan Tiang Kee, in Batavia in 1834. Whether this nephew was the son of Tan Kim Lin is unknown as the name cannot be found in the family tree book. Captain Tan Phan Long also initiated the reconstruction of the kelenteng Talang, located in Jalan Talang. The temple had been an Ancestral Hall Temple of the Tan family and was first built in 1790 in the grounds of the Tiao Kak Sie Temple, on the initiative of Captain Tan Oat Ing. The reconstruction of the temple was completed by Captain Khoe Tiauw Jang in 1848.

In 1842 the Dutch found it necessary to appoint another officer in Cirebon to assist Captain Tan Phan Long. Khoe Tiauw Jang was installed as Lieutenant. He replaced Tan Phan Long as Captain in 1846, when the latter retired. In 1846, Tan Tiang Keng, the son of Captain Tan Kim Lin, was installed in his turn as lieutenant to assist the new captain. In 1853, probably at the captain's request, another lieutenant was appointed. He was Captain Khoe Tiauw Jang's

\footnotetext{
8 In the marriage register, the signatures of the bride and groom were usually accompanied by those of witnesses from both sides. The go-between male/female would also be present and their names were recorded. Also noted was the family relationship of the witness to the bride or groom, such as father, brother, uncle, or grandfather of the bride. In most cases, witnesses were older than the bride or the groom. The problem was that witnesses were sometimes adopted uncles or elder cousins. When a new "fresh" immigrant who had no close relatives got married, he would have chosen someone older with the same surname to be his witness.

9 Chen Menghong 2011: 207.

10 The Wees- en Boedelkamer was an institution in charge of orphans and probate. It was usual that one or two Chinese were appointed to deal with issues related to the Chinese community and they received the honorary rank/title.

11 Chen Menghong 2011: 38.

12 Franke, Salmon, and Hu 1997 II/1: 249.
} 
son, Khoe The Djin. This was probably the reason that, when Captain Khoe Tiauw Jang died in 1855, Khoe The Djin was promoted to the rank of Captain instead of Tan Tiang Keng, who was more senior and had served longer as Lieutenant. After Khoe The Djin was promoted Captain, the Dutch installed another lieutenant: Lieutenant Yoe Ong Pauw.

Unfortunately, there are no further data about Captain Khoe Tiauw Jang. The only information found about his son, Captain Khoe The Djin, was about a case involving The Tiang Seng ${ }^{13}$ and his son, the later Captain The Tjiauw Tjay. In newspaper clippings from 1866, we can read all about the affair. The Tiang Seng accused the Captain of adulterating opium (by adding some kinds of substances in its preparation), but the court dismissed the accusation. We can assume that Captain Khoe The Djin held the opium concession at that time. In another newspaper clipping from 1877, we learn that The Tiang Seng was sent to jail for four years after he was found guilty of smuggling opium. The only information found about Lieutenant Yoe Ong Pauw was that he owned a sugar factory in Kali Tanjung. ${ }^{14}$ In 1874, Lieutenant Yoe Ong Pauw submitted his resignation, and he was replaced by Lieutenant The Tjiauw Tjay.

THE FAMILIES OF THE FOUR BIG OFFICERS (1874-1919)

In 1873, after twenty-six years service as lieutenant, the Dutch wanted to reward Lieutenant Tan Tiang Keng for the exemplary performance of his duties. They awarded him the title of Honorary Captain. He was still only forty-seven at the time. The next year Lieutenant Yoe Ong Pauw resigned, and he was replaced by Lieutenant The Tjiauw Tjay. The Dutch appointed two more lieutenants for the regions outside of Cirebon, namely: Lieutenant Oey Thiam Seng for the west and northwestern parts of the city, and Lieutenant Kwee Boen Pien for the eastern and southeastern parts respectively. Lieutenant Oey Thiam Seng resided in the village of Jamblang, while Lieutenant Kwee Boen Pien lived in the village of Ciledug. The installation of these three officers marked the formation of four influential families/clans in Cirebon, namely: the Tan and The families in Cirebon itself, and the Oey family in Jamblang and the Kwee family in Ciledug. The structure was one captain with two lieutenants in the city itself and two lieutenants outside the city. The background family histories of these four big families (see Figure 1) will be described below. 


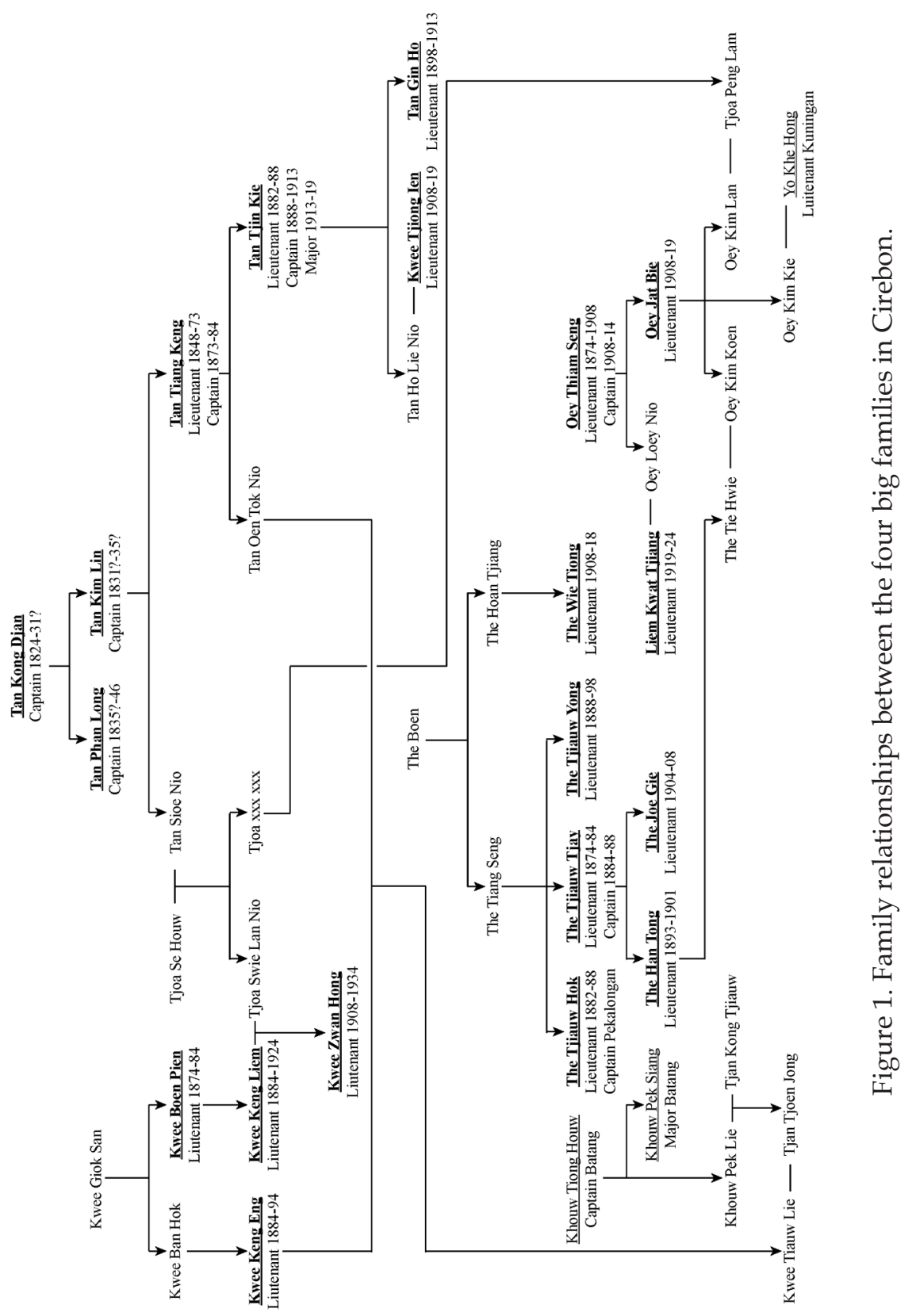


Captain Khoe The Djin passed away in 1882 as the most senior member of the Chinese officers in Cirebon, and Honorary Captain Tan Tiang Keng became the regular captain in 1882. Two months later his son, Tan Tjin Kie, was installed as lieutenant. In 1882, there was also a honorary lieutenant in Cirebon, Lieutenant The Tjiauw Hok, a younger brother of Lieutenant The Tjiauw Tjay. He was awarded the honorary title because he was a member of the board of the Wees-en Boedelkamer. After only serving two years as captain, Tan Tiang Keng passed away in 1884 at the age of fifty-nine. He was replaced by the most senior lieutenant at that time, The Tjiauw Tjay, who was thirtythree years old. Actually, Lieutenant Oey Thiam Seng was older in age, but he had been installed as lieutenant later than Captain The Tjiauw Tjay, and he was not a resident of the city of Cirebon. To fill the vacancy of the lieutenant rank, Kwee Keng Eng was installed to this rank in Cirebon. He was a nephew of Lieutenant Kwee Boen Pien and son-in-law of Captain Tan Tiang Keng. At the end of the same year, Lieutenant Kwee Boen Pien also passed away. He was replaced as lieutenant by his oldest son, Kwee Keng Liem.

In March 1888, Captain The Tjiauw Tjay became ill and he wished to retire. His request was granted by the Dutch government, and he was allowed to use the title of honorary captain. The captaincy passed into the hands of Tan Tjin Kie, the late Captain Tan Tiang Keng's eldest son. Later that year, Honorary Captain The Tjiauw Tjay also passed away. He was then thirty-seven years old. His younger brother, Honorary Lieutenant The Tjiauw Hok, ${ }^{15}$ had moved to Pekalongan, so he could not succeed his brother in Cirebon. The next brother, The Tjiauw Yong, became lieutenant in Cirebon.

In 1893, Lieutenant Kwee Keng Eng submitted a request to retire, and he was replaced in 1894 by Lieutenant The Han Tong, the eldest son of the late Captain The Tjiauw Tjay. In 1897, Lieutenant The Tjiauw Yong passed away, and he was replaced in turn by Tan Gin Ho, the eldest son of Captain Tan Tjin Kie. In 1901, Lieutenant The Han Tong passed away at an early age. His younger brother, The Joe Gie, succeeded him two years later. In 1907, Lieutenant Tan Gin Ho requested a long holiday and asked that he would be replaced, so Captain Tan Tjin Kie's son-in-law, Kwee Tjiong Ien, was installed as acting lieutenant. After Tan Gin Ho returned from his holiday in 1909, Kwee Tjiong Ien handed back his rank of lieutenant. In 1908, some mutations occurred among the Chinese officers in Cirebon. Lieutenant Oey Thiam Seng retired with the title of Honorary Captain. His place was taken by his son, Oey Jat Bie. Kwee Keng Liem also retired and was replaced by his eldest son, Kwee Zwan Hong. In contrast to Honorary Captain Oey Thiam Seng, Lieutenant Kwee Keng Liem received only the rank of Honorary Lieutenant. Lieutenant The Joe Gie requested to be relieved as lieutenant because he was no longer resident in the city of Cirebon. At that time, he lived in Kuningan, that was actually outside the prefecture of Cirebon. Lieutenant The Wie Tiong, a distant uncle of Lieutenant The Joe Gie, was installed to replace him. 


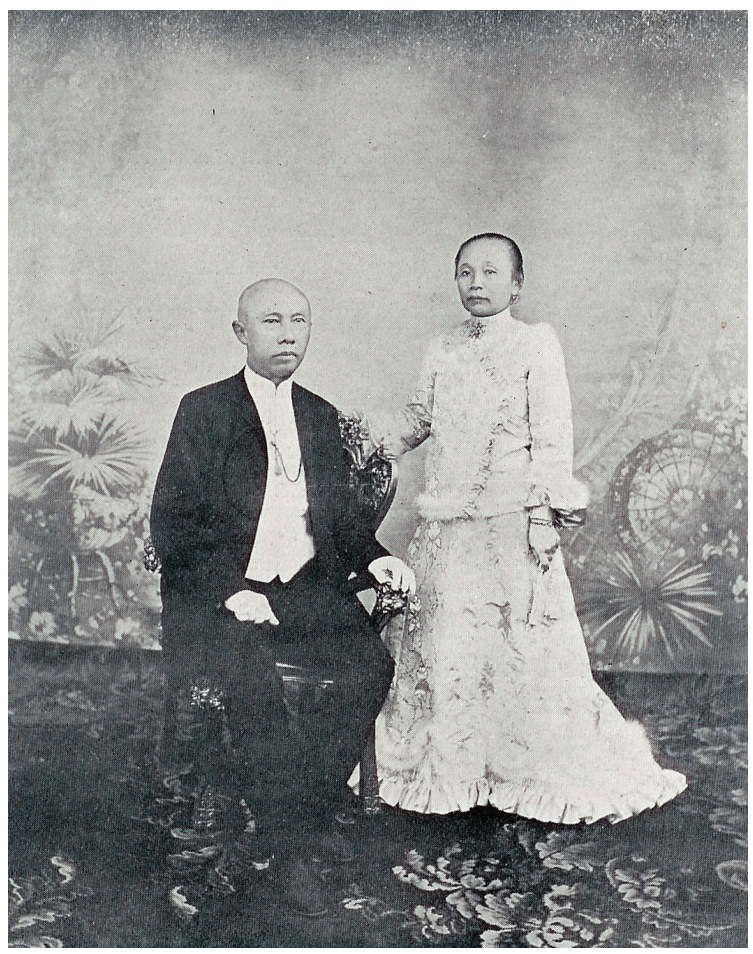

Figure 2. Honorary Major Tan Tjin Kie with his wife Ong Hwie Nio (courtesy of Tan Gin Ho from his book).

In 1913, the Dutch awarded Captain Tan Tjin Kie the rank of Honorary Major (see Figure 2). This was the highest rank ever given to a Chinese officer in Cirebon. In the same year, Lieutenant Tan Gin Ho resigned as lieutenant and was replaced by his brother-in-law, Kwee Tjiong Ien. In 1918, Lieutenant The Wie Tiong went bankrupt, ${ }^{16}$ and it was the custom that a Chinese officer resigned after bankruptcy. In 1919, Lieutenant Oey Jat Bie passed away, and not long after that, both Honorary Major Tan Tjin Kie and his son in law (Lieutenant Kwee Tjiong Ien) also passed away. Lieutenant Oey Jat Bie was replaced by his brother-in-law Liem Kwat Tjiang. There was for some reason until the next year no lieutenant in Cirebon to replace the three officers who resigned and passed away. Probably they had not found the right person for the position of lieutenant. Hereafter Oey Thiam Tjoan was installed as lieutenant. He was not related to Honorary Captain Oey Thiam Seng from Jamblang.

\section{The TAn FAmiLy}

The Tan family of Major Tan Tan Tjin Kie was an old Cirebon Peranakan family. We have already mentioned that his great-grandfather, Tan Kong Djan, was installed as captain between 1823 to 1830 . Very probably the family 
originally came from Batavia where it had had a close relationship with the Tan family. As already mentioned, Lieutenant Tan Pin Long, Captain Tan Kim Lin, and Captain Tan Phan Long were brothers, and Lieutenant Tan Pin Long resided in Batavia.

Captain Tan Kim Lin founded the sugar factory Luwunggajah (written in the old text as: Loewoenggadjah) in 1828. Later, this sugar business became the core business of his family. The family tree book states that Tan Kim Lin had two sons, Tan Tiang Keng and Tan Tiang Eng. In the marriage register in the Batavia Kong Koan Archives, there is a record that Captain Tan Phan Long attended the wedding ceremony of a nephew named Tan Tiang Kee in 1835. Later, in 1862, Tan Tiang Kee had the title of officer when he was noted as attending the wedding ceremony of his daughter and the only officer named Tan Tiang Kee was Lieutenant Tan Tiang Kee from Karawang (1854-1857). Whether this Tan Tiang Kee was the son of Captain Tan Kim Lin or of an unknown brother of Captain Tan Phan Long remains uncertain. ${ }^{17}$

Captain Tan Tiang Keng inherited the sugar factory from his father. He had two sons, Tan Tjin Kwee and Major Tan Tjin Kie. Probably, Tan Tjin Kwee was disabled as he neither became an officer nor was he officially married. Tan Tiang Keng also had two daughters. The second, Tan Oen Tok Nio, was married to Lieutenant Kwee Keng Eng. Here begins the complicated family relationship with the Kwee family of Ciledug as Lieutenant Kwee Keng Liem was married to Tjoa Swie Lan Nio, a niece of Captain Tan Tiang Keng, the daughter of his younger sister Tan Sioe Nio, who was herself married to Tjoa Se Houw. Captain Tan Tiang Keng adopted Tan Tjin Wie, the eldest son of his brother Tan Tiang Eng.

Major Tan Tjin Kie also had two sons, Lieutenant Tan Gin Ho and Tan Gin Han, and one daughter, Tan Ho Lie Nio. He also adopted Tan Tjin Wie's son, Tan Boen Liong. Tan Ho Lie Nio married Lieutenant Kwee Tjiong Ien from the Kwee family in Malang. During his lifetime Major Tan Tjin Kie was very socially active. He contributed to many charitable organizations and he donated money to build a hospital and a mosque for the workers in his sugar factory. He was also very well respected on all levels of society by many people. He was respected by the Chinese, enjoyed a good relationship with the ordinary Javanese and with the bupati (Dutch: regent), and was highly regarded in the Dutch community as well. Therefore, when he died, many of his acquaintances from outside Cirebon attended his funeral, as recorded in his son's, Tan Gin Ho, notes (1919). Representatives of the Governor-General in Batavia, of the Sunan of Surakarta, of the Republic of China, as well as various officers from other cities all paid their respects to the deceased Major.

Each of Major Tan Tjin Kie's two sons had different character. Lieutenant Tan Gin Ho was a calm man, deeply devoted to Buddhist teaching. His younger brother, Tan Gin Han, was more flamboyant, more like the usual

17 Captain Tan Pin Long's sons used the name Siauw as generation (middle) name. Captain Tan Phan Long's sons used the name Tjoan and Captain Tan Kim Lin's sons used the name Tiang for this purpose. 
idea of an officer's son. Major Tan Tjin Kie and his wife loved their only daughter, Tan Ho Lie Nio, so much that he built her a beautiful mansion as her wedding present. Unfortunately, her own husband died young in 1919, and in $1921^{18}$ she was forced to sell the mansion to the creditors of her late husband's company. In $1926^{19}$ she was declared bankrupt.

After the end of World War I, the financial problems in the sugar business were obvious to all. Almost without exception, sugar factories went bankrupt and were taken over by their creditors. The sugar factory Luwunggajah, which the family was forced to sell to pay for their debts in 1922, suffered the same fate. ${ }^{20}$ How much the family received from the deduction of the debt is not known; nevertheless, in 1931 Tan Gin Ho and Tan Gin Han were declared bankrupt. ${ }^{21}$

The Tan family had owned several mansions in the past. The most famous stood in Jalan Pasuketan. The house still exists, although it was no longer a family property. The house in Binarong, near the sugar factory, was demolished. The family also owned another property, that is now used as a Roman Catholic school.

\section{THE THE-FAMILY}

The first officer from this family, Captain The Tjiauw Tjay (see Figure 3), was the grandson of The Boen who came from the village of Jinyang, Fujian. The family was traditionally involved in the shipping business. The Boen began this business, and it survived until Japan invaded Indonesia and confiscated all the ships; albeit big ships were no longer sailing between the cities in 1941.

The second generation, The Tiang Seng, Captain The Tjiauw Tjay's father, tried to expand the business by competing with Captain Khoe The Djin for the opium concession. Therefore it seems plausible to assume that the 1866 incident between The Tiang Seng and Captain Khoe The Djin was caused by the rivalry between the two opium-farmers. From the newspaper clipping from the year $1877,,^{22}$ we learn that The Tiang Seng and his brother had been found guilty of opium smuggling and sentenced to four years' hard labour. Probably, as the family did not know where he was buried, The Tiang Seng did not survive and died in prison. His brother did survive and was still active in the opium business at a later date. At that time, ${ }^{23}$ the installation of The Tjiauw Tjay as lieutenant also surprised some people as he was the son of a convicted criminal. The rivalry between the Khoe and the The was kept alive when Captain Khoe The Djin accused Lieutenant The Tjiauw Tjay (at that time the opium-farmer) of possessing more opium than was permitted. ${ }^{24}$

\footnotetext{
Bataviaasch Nieuwsblad 3-11-1921: 7.

Bataviaasch Nieuwsblad 2-11-1926: 9.

Het Nieuws van den Dag voor Nederlandsch-Indië 1-6-1922: 4.

De Indische Courant 6-10-1931: 11.

Java Bode; Nieuws, Handels- en Advertentieblad voor Nederlandsch-Indië 27-7-1877: 3.

Java Bode; Nieuws, Handels- en Advertentieblad voor Nederlandsch-Indië 20-11-1874: 3.

24 De Locomotief; Samarangsch Handels- en Advertentieblad 11-4-1883: 1.
} 
Some years later, before he was promoted to be Captain, we read that The Tjiauw Tjay had tried to sell his opium concession.

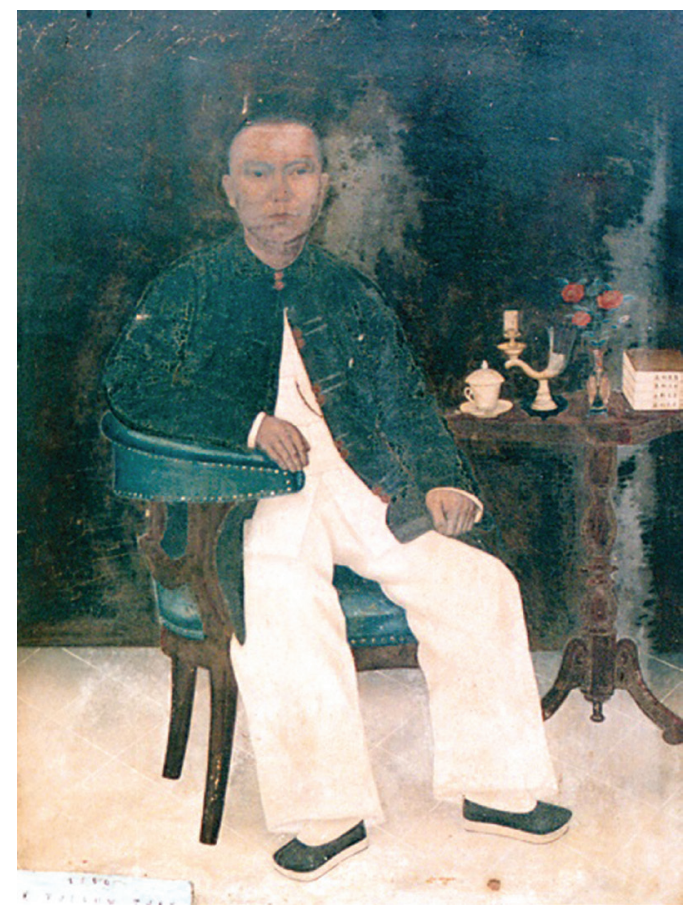

Figure 3. Captain The Tjiauw Tjay (courtesy of the Captain's family).

Captain The Tjiauw Tjay had two younger brothers who also became officers. Honorary Lieutenant The Tjiauw Hok moved to Pekalongan in 1888 and became Captain there in 1897. He served until he passed away in 1913. His son, The Khe Bouw, was installed as lieutenant in the same year and resigned in 1924 because he had been declared bankrupt. After Captain The Tjiauw Tjay passed away, his brothers continued their opium business with their uncle and, after their uncle's death, with their cousin. Lieutenant The Tjiauw Jong, the youngest brother who died in 1897, was reported in the newspaper to have been a very rich man. ${ }^{25}$ Captain The Tjiauw Hok, who died in 1913, bequeathed half a million Dutch florins to each son, but within ten years his eldest son, Lieutenant The Khe Bouw, had squandered his money.

In his term as captain, The Tjiauw Tjay initiated the renovation of the Tiao Kak Sie Temple. The family also gave a large donation for the renovation. Unfortunately, the renovation was still unfinished when he passed away. Before that, in 1884, he also gave a donation for the building of another Chinese temple in Bandung.

Captain The Tjiauw Tjay had three sons. The eldest son, Lieutenant The Han Tong, was probably was prepared to be the next captain should Captain Tan Tjin Kie pass away. Lieutenant The Han Tong was twenty-four years old

25 Soerabaijasch Handelsblad 16-8-1897: 5. 
when he was installed, sadly he died seven years later, aged only thirty-one. He was married to the sister of Honorary Major Khouw Pek Siang's wife. It seems that the The-family clan was excluded by other family clans from contracting marriages with them. The Tan and the Kwee were closer because of their shared business interests. Only in the generation of The Han Tong did they marry members of other officers' families. Lieutenant The Han Tong's eldest daughter was married to the brother of the Lieutenant of Kudus and, after her divorce, she remarried the Honorary Captain of Bandung. His eldest son was married to the youngest daughter of Lieutenant Oey Jat Bie from Jamblang. His second son and second daughter were married to the daughter and son of Major Khouw Pek Siang (in fact these were full cousin intermarriages).

When Lieutenant The Han Tong passed away at the age of thirty-one, his children were raised by his younger brother, Lieutenant The Joe Gie, who also took over the family shipping and construction businesses, but when the children reached maturity, he returned them the businesses which were already in decline since their glory days.

The last Chinese officer from the The-family was Lieutenant The Wie Tiong. He was the second $\operatorname{son}^{26}$ of The Hoan Tjiang, the youngest son of The Boen. In the old newspapers, all we could find was that he was involved in postal and delivery services for local government businesses from 1897 to 1901. ${ }^{27}$ He was declared bankrupt in 1918 and resigned as Chinese officer. After he was relieved of his duty, The Wie Tiong was active in various local Chinese associations.

The family house of the The-family was in what is now Jalan Benteng near the Tiao Kak Sie Temple. The main family house (probably of the The Tiang Seng branch) was sold in 1910s and demolished when the Japanese came. It is now a through street. A smaller house (probably of the The Hoan Tjiang branch) still exists, although the front of it was sold off.

\section{The Oey family}

Who was the first ancestor of the Oey family from Jamblang who landed in Java is not known. The family tree can only be traced back to Oey Thiam Seng, who settled in the village of Jamblang, 15 kilometers west of Cirebon. His main businesses were tapioca production and forestry. There is a strong possibility that Oey Thiam Seng was related to Captain Oey Ek Kiam from Meester Cornelis (Jatinegara), as Captain Oey Thiam Seng attended the marriage registration of Captain Oey Ek Kiam's daughter in 1913, as witness for the bride and is recorded as an uncle of the bride. ${ }^{28}$

More information about Oey Thiam Seng (see Figure 4) was found in the

\footnotetext{
26 The eldest son, according to the family record, moved to and lived in Pekalongan.

27 Java Bode; Nieuws, Handels- en Advertentieblad voor Nederlandsch-Indië 9-12-1896: 2.

28 Attending a wedding in another city at that time must have been an arduous journey for a man as old as Captain Oey Thiam Seng. Consequently, the family in Batavia must have had a very important relationship with the Oey family in Jamblang to motivate him to expend time and effort to attend the wedding.
} 
Chinese temple in Jamblang, of which he was one of the founders in 1868. According to the written history of the temple, before becoming lieutenant in 1874 , he was installed as ward master in 1868 . He had only one son, Lieutenant Oey Jat Bie, and one daughter by his principal wife. ${ }^{29}$ His daughter married Lieutenant Liem Kwat Tjiang.

Lieutenant Oey Jat Bie had four daughters and four sons. The youngest son died unmarried. Via his oldest daughter, the Oey clan was related to the Tan family. She married Tjoa Peng Lam, the grandson of Tan Sioe Nio and Tjoa Se Houw. Tan Sioe Nio was the sister of Captain Tan Tiang Keng. Lieutenant Oey Jat Bie's second daughter was married to Lieutenant Yo Khe Hong from Kuningan. The youngest daughter, as described above, was married to the eldest son of Lieutenant The Han Tong. Lieutenant Oey Jat Bie's eldest son was once married to the daughter of Tan Tjin Wie, who was Major Tan Tjin Kie's adopted brother. This marriage seems to have been a failure as they were later divorced.

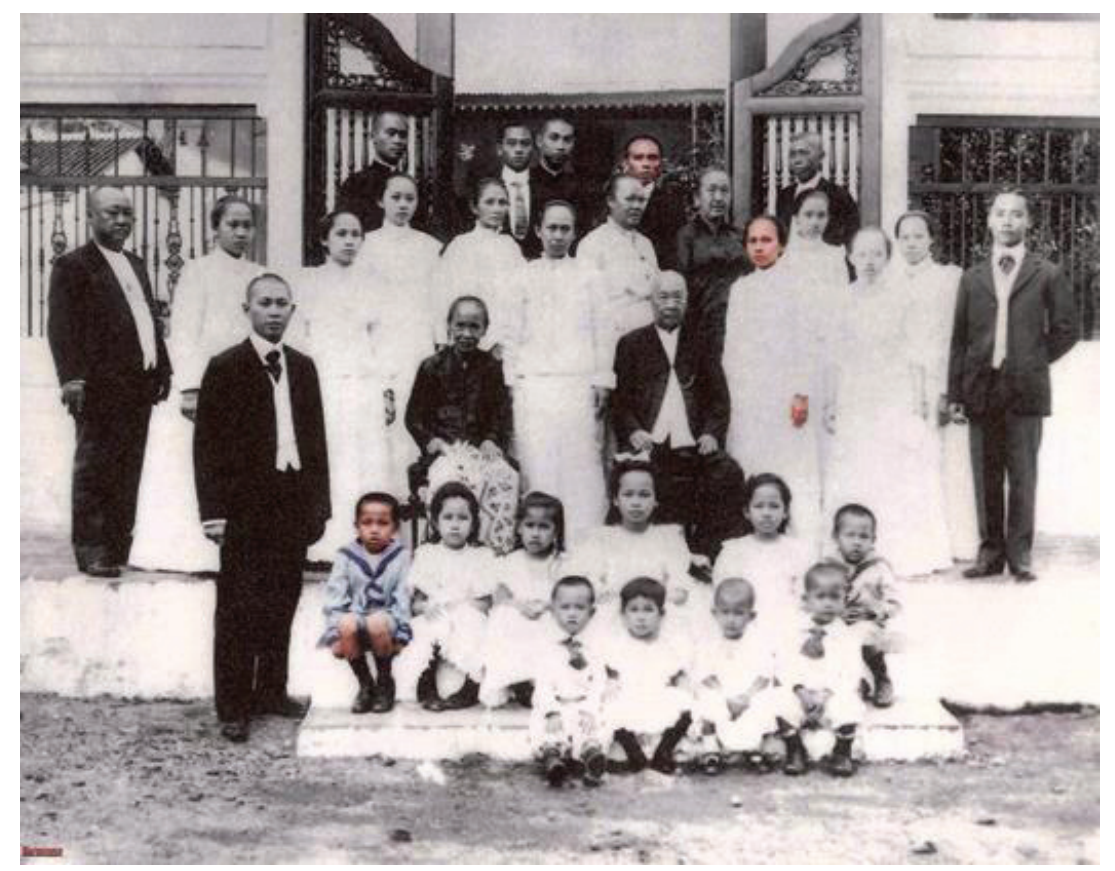

Figure 4. Family of Captain Oey Thiam Seng with his son Lieutenant Oey Jat Bie on the far left and his son-in-law Lieutenant Liem Kwat Tjiang far right on the back row (courtesy of the Oey's family).

There was no background information about the past of Lieutenant Liem Kwat Tjiang. He is known to have supplied the sugar factory with sugarcane seeds in $1893 .{ }^{30} \mathrm{He}$ also acquired the concession for the transportation of government

29 Captain Oey Thiam Seng had a native Javanese as a concubine and had two daughters by her.

30 Bataviaasch Nieuwsblad 17-06-1893: 17. 
goods within the Cirebon prefecture from 1896 to $1900 .{ }^{31}$ Later, he joined the family business of Captain Oey Thiam Seng that was trading secondary crops. After his brother-in-law, Lieutenant Oey Jat Bie, passed away in 1919, he took over the company but the difficult economic conditions post-World War I accelerated the decline of the business. Lieutenant Liem Kwat Tjiang resigned as Chinese officer in 1924 and was granted the right to use the title of Honorary Lieutenant. ${ }^{32}$

In Jamblang the Oey family resided in a big mansion near the Chinese temple. The house still exists but it was sold and was turned into a bird's nest house. The house of Liem Kwat Tjiang, that was sold to a rice trader from another city as his wealth dwindled, was on the main road to Bandung.

\section{THE KWEE FAMILY}

The founding ancestor of the Kwee family was Kwee Giok San. He was born in Longxi, Fujian. According to the family story, he landed in Ciledug and became a trader. His second son, Kwee Boen Pien, ${ }^{33}$ became the owner of the sugar factory Jatipiring (old spelling: Djatipiring) in Ciledug. ${ }^{34}$ Lieutenant Kwee Boen Pien had four sons. The eldest son, Kwee Keng Liem, would succeed him as lieutenant and inherit the sugar factory. The two youngest sons were married to descendants of the Liem family from Tegal and moved there.

Lieutenant Kwee Keng Liem married twice. His first marriage was to Tjoa Swie Lan Nio, the cousin of Major Tan Tjin Kie. From his first marriage he had one son, Kwee Zwan Hong, and two daughters, Kwee Siang Nio and Kwee Ay Lien. Kwee Siang Nio married Kho Yoe Keng, the younger brother of Honorary Lieutenant Kho Yoe Seng from Sokaraja. Kwee Ay Lien was married to Khoe Swie Ho. According the family story, he was a descendant of Captain Khoe The Djin, but there was no further hard evidence to confirm this. Kwee Zwan Hong married twice, the first time to Tan Bie Nio and the second time to Lim Ke Tie Nio, the daughter of Lieutenant Liem Goan Tjeng of Batavia.

After Tjoa Swie Lan Nio passed away, Lieutenant Kwee Keng Liem married Tan Hok Nio (Figure 5), a great-niece of Lieutenant Tan Kong Hoa of Batavia and Lieutenant Tan Yoe Hoa of Bekasi. From his second marriage, Lieutenant Kwee Keng Liem had three more sons, namely: Kwee Zwan Lwan, Kwee Zwan Liang, Kwee Zwan Ho, and one daughter, Kwee Der Tjie Nio. Kwee Zwan Lwan was married to Be Khiam Nio, the daughter of Honorary Major Be Kwat Koen of Surakarta, Kwee Zwan Liang was married to Liem Hwat Nio from a prominent Liem family in Surabaya, and Kwee Zwan Ho was married to Tan Ing Nio, the granddaughter of Captain Tan Goan Piauw

\footnotetext{
31 De Locomotief; Samarangsch Handels- en Advertentieblad 30-12-1895: 3.

Het Nieuws van den Dag voor Nederlandsch-Indië 8-10-1924: 13.

33 Peter Post (2004: 7) wrote that the sugar factory was founded by Lieutenant Kwee Keng Liem. But when Kwee Boen Pien was installed as Lieutenant in 1874, he was said to be a sugar factory owner.

34 Handelingen Staten Generaal; Zitting 1886-1887: “Kwee Boen Pien acquired the sugar factory Jatipiring in $1873^{\prime \prime}$.
} 
of Buitenzorg (Bogor). Kwee Der Tjie Nio was married to Han Tiauw Bing of the Han family of Pasuruan and moved to Lawang.

Lieutenant Kwee Keng Liem passed away in 1924, and the four sons took over the sugar factory. Not long after that, the three younger brothers bought the sugar factory from their oldest brother, Lieutenant Kwee Zwan Hong. The factory was sold in 1931 because of the financial crisis. The Kwee's brothers, apart from Kwee Zwan Liang, first lived in Ciledug at the factory but later moved to Linggarjati (old spelling: Linggadjati). In 1947, their houses were used by the Dutch delegation during the Linggarjati agreement negotiations.

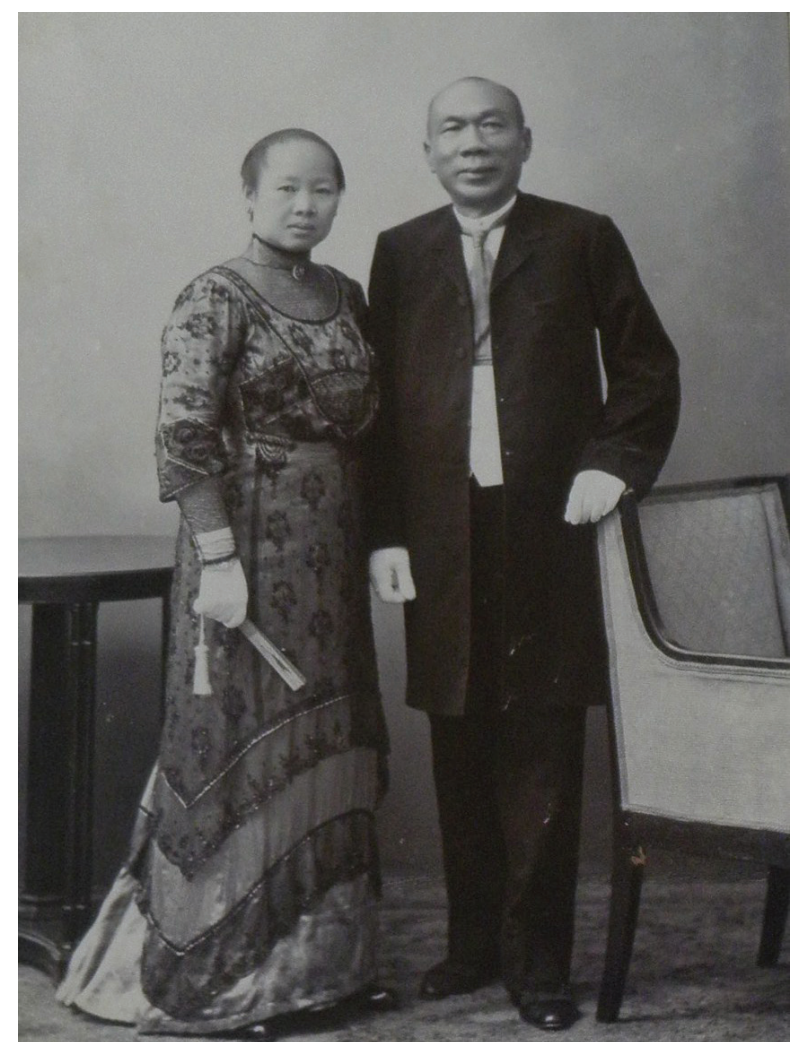

Figure 5. Lieutenant Kwee Keng Liem with his second wife Tan Hok Nio (the photograph was taken from "Peranakan people pictures portraits and paintings" on a Facebook page).

In March 1923, Lieutenant Kwee Zwan Hong received a decoration from the Republic of China (Fourth-grade Order of Golden Rice Stalk). ${ }^{35}$ Later that year, he was promoted to Honorary Captain. He requested to be relieved of his duties as a Chinese officer in 1928 and, although his request was granted, the day it was supposed to come into effect it was postponed. ${ }^{36}$ In 1935, after the institution of Chinese officer had been abolished, Honorary Captain Kwee 
Zwan Hong received another decoration from the Dutch Queen (Small Golden Star for Loyalty and Merit). ${ }^{37}$ He lived in Cirebon and also still kept a house in Ciledug. He passed away in 1955.

Besides the family of Kwee Boen Pien, there was another Kwee who became a Chinese officer in Cirebon. He was Kwee Keng Eng, who was the son of Kwee Ban Hok, an older brother of Kwee Boen Pien. He married Tan Oen Tok Nio, the younger sister of Major Tan Tjin Kie. Like his cousin, Kwee Keng Eng owned a sugar factory in Kali Tanjung, that had probably once been owned by Lieutenant Yoe Ong Pauw. Kwee Keng Eng and Tan Oen Tok Nio had only one daughter, Kwee Tiauw Lie, who married Tjan Tjoen Jong, the nephew of Major Khouw Pek Siang of Batang. Kwee Keng Eng adopted a son, Kwee Zwan Jam, who was married to Aw Kiok Lan Nio, the daughter of Lieutenant Aw Seng Hoe of Majalengka.

There is no significant information about Kwee Keng Eng after he resigned as Lieutenant in 1893. In 1902, the sugar factory at Kali Tanjung was auctioned, ${ }^{38}$ meaning that for some reason or other the family had relinquished its ownership. In 1905, several auction sales of houses owned by Kwee Keng Eng and his brother Kwee Keng Po were documented. Ex-Lieutenant Kwee Keng Eng died in 1916 after consuming poisonous mushrooms. ${ }^{39}$

\section{The last Chinese officers in Cirebon}

In 1920, Oey Thiam Tjoan was installed as lieutenant. He was a trader and third-generation Peranakan. It was his grandfather, Oey Tjong Boen, who had come to Cirebon and settled there. Oey Tjong Boen's youngest son, Oey Keng Tjay, became a successful trader and a prominent man in Cirebon and, after he passed away, his eldest son, Oey Thiam Tjoan, succeeded him in the business. Consequently, it is not surprising that he was chosen to be the next Chinese officer. In 1924, Lieutenant Oey Thiam Tjoan was promoted to captain. Tan Wan Hoey was installed as Lieutenant. But within a year, in 1925, Captain Oey Thiam Tjoan's business empire collapsed and he was declared bankrupt and he was forced to resign.

Lieutenant Tan Wan Hoey was the eldest son of Tan Thay Hok. This Tan family was not directly related to the family of the Major Tan Tjin Kie. As the family of Oey Keng Tjay, the family of Tan Kong Boen (Tan Thay Hok's father) grew wealthy at the end of the nineteenth century. Tan Thay Hok, his eldest son, was married to Lie Na Nio, a cousin of Major Lie Tjoe Hong of Batavia. Because of his wealth and his social connections, Tan Thay Hok can be regarded as a prominent figure in Cirebon. The family enjoyed a respect equal to that of the Tan family (of Tan Tjin Kie), the The-family and the Oey family. He had business interests in sugar, coal-mining and rubber plantations (?). He visited the Ahi Mansion in Singapore regularly. Tan Wan Hoey and 
his younger brother, Tan Wan Liat, succeeded their father after he (the father) passed away in 1921.

Lieutenant Tan Wan Hoey was installed in 1924, but several court cases in Singapore damaged his reputation; ${ }^{40}$ as a result, he resigned as Lieutenant in 1926. He was replaced by Lieutenant Tjan Kim Ie, who served until 1929. Unfortunately, there is no information about Lieutenant Tjan Kim Ie available .

The last remaining officer in Cirebon was Kwee Zwan Hong. Although he had requested to be relieved and this request was granted, he was still considered Captain of the Cirebon Chinese community until 1934.

\section{EPILOGUE}

In 1934, the institution of Chinese officer in Java was abolished. Their duties were taken over by the ward masters who were salaried officials of the Dutch colonial government, with the exception of Batavia where the ranks of major, captain, and lieutenant continued to exist until the Japanese invaded Indonesia in 1942. Beyond Java, the Chinese officers were still active after 1934, but the office ended in 1942. The local Chinese officers were usually only well known in their own regions. In the case of the Chinese officers in Cirebon, only Major Tan Tjin Kie acquired some fame outside the city, because of his well-attended funeral and the book written by his son. However, the officers were prominent figures in the local Chinese community in Cirebon.

\section{THE LIST OF OFFICERS IN CIREBON}

Tan Siang Ko - Captain (1705-1720)

Tan Oat Ing - Captain (1790)

Tan Soe Tje - Captain (1823)

Tan Kong Djan - Captain (1824-1831?)

Tan Jong Goan (Tan Kim Lin ?) - Captain (1831?-1835)

Tan Phan Long - Captain (1836-1846)

Khoe Tiauw Jang - Lieutenant (1842-1846) - Captain (1846-1855)

Tan Tiang Keng - Lieutenant (1848-1873) - Honorary Captain (1873-1882) Captain (1882-1884)

Khoe The Djin - Lieutenant (1853-1855) - Captain (1855-1882)

Yoe Ong Pauw - Lieutenant (1855-1874)

The Tjiauw Tjay - Lieutenant (1874-1884) - Captain (1884-1888)

Kwee Boen Pien - Lieutenant (1874-1884)

Oey Thiam Seng - Lieutenant (1874-1908) - Honorary Captain (1908-1913)

Tan Tjin Kie - Lieutenant (1882-1888)-Captain (1888-1913) - Honorary Major (1913-1919)

The Tjiauw Hok - Honorary Lieutenant (1882-1888)

Kwee Keng Eng - Lieutenant (1884-1894)

Kwee Keng Liem - Lieutenant (1884-1908) - Honorary Lieutenant (1908-1924)

The Tjiauw Yong - Lieutenant (1888-1897) 
The Han Tong - Lieutenant (1894-1901)

Tan Gin Ho - Lieutenant (1898-1913)

The Joe Gie - Lieutenant (1904-1908)

Kwee Tjiong Ien - Acting Lieutenant (1907-1910) - Lieutenant (1913-1919)

Oey Jat Bie - Lieutenant (1908-1919)

Kwee Zwan Hong - Lieutenant (1908-1923) - Honorary Captain (1923-1934)

The Wie Tiong - Lieutenant (1908-1918)

Liem Kwat Tjiang - Lieutenant (1919-1924) - Honorary Lieutenant (1924-19??)

Oey Thiam Tjoan - Lieutenant (1920-1924) - Captain (1924-1925)

Tan Wan Hoey - Lieutenant (1924-1926)

Tjan Kim Ie - Lieutenant (1926-1929)

\section{REFERENCES}

Chen Menghong. 2011. De Chinese gemeenschap van Batavia, 1843-1865; Een onderzoek naar het Kong Koan-archief. Leiden: Leiden University Press.

Franke, Wolfgang, Claudine Salmon, and Hu Chün-Yin. 1997. Chinese epigraphic materials in Indonesia. Vol. 2: Java. Singapore: South Seas Society.

Lohanda, Mona. 1996. Kapitan Cina of Batavia; A history of Chinese sstablishment in colonial society. Jakarta: Djambatan.

Post, Peter. 2004. “The Kwee home movies; A new resource for the study of the life of the Peranakan elite in colonial Java", CHC Bulletin 4 (December): 6-10.

Regerings-almanak Nederlandsch-Indië: 1815-1942. 2008. Den Haag: Centraal Bureau voor Genealogie.

Tan Gin Ho. 1919. Buku peringetan dari wafatnja Majoor Tan Tjin Kie (Tan Keng Bie). Batavia/Cheribon: Kolff.

NEWSPAPERS

Bataviaasch Nieuwsblad 17-6-1893.

Bataviaasch Nieuwsblad 3-11-1921.

Bataviaasch Nieuwsblad 2-11-1926.

De Handelingen der Staten Generaal; Zitting 1886-1887: “Kwee Boen Pien acquired the sugar factory Jatipiring in 1873".

De Indische Courant 6-10-1931.

De Locomotief 11-04-1883.

De Locomotief; Samarangsch Handels- en Advertentieblad 6-7-1866.

De Locomotief; Samarangsch Handels- en Advertentieblad 11-4-1883.

De Locomotief; Samarangsch Handels- en Advertentieblad 30-12-1895.

De Locomotief; Samarangsch Handels- en Advertentieblad 27-9-1902.

De Preanger Bode 25-1-1916.

De Preanger Bode 19-4-1923.

Het Nieuws van den Dag voor Nederlandsch-Indië 15-10-1918: 10.

Het Nieuws van den Dag voor Nederlandsch-Indië 1-6-1922

Het Nieuws van den Dag voor Nederlandsch-Indië 8-10-1924.

Java Bode; Nieuws, Handels-en Advertentieblad voor Nederlandsch-Indië 20-11-1874. 
Java Bode; Nieuws, Handels- en Advertentieblad voor Nederlandsch-Indië 27-7-1877. Java Bode; Nieuws, Handels- en Advertentieblad voor Nederlandsch-Indië 9-12-1896 Javasche Courant 9-7-1934. Javasche Courant 9-9-1837.

Rotterdamsche Courant 24-11-1860.

Soerabaijasch Handelsblad 16-8-1897.

Soerabaijasch Handelsblad 2-4-1929.

Soerabaijasch Handelsblad 4-1-1935.

The Singapore Free Press and Mercantile Advertiser 9-3-1927. 